\title{
ERRATUM
}

Yong-Jin Lee · Isaac D. Wagner · Mary E. Brice

Vadim V. Kevbrin · Gary L. Mills

Christopher S. Romanek · Juergen Wiegel

\section{Thermosediminibacter oceani gen. nov., sp. nov. and Thermosediminibacter litoriperuensis sp. nov., new anaerobic thermophilic bacteria isolated from Peru Margin}

Published online: 11 April 2006

(C) Springer-Verlag 2006

\section{Extremophiles (2005) 9:375-383}

Unfortunately, incorrect values of the mol \% G+C were reported for the type species and type strains in Lee et al., Extremophiles 9:375-383 (2005) in the Abstract on page 375: "The $\mathrm{G}+\mathrm{C}$ content of the DNA was $50 \mathrm{~mol} \%$ for both ..."; page 380: "The G+C contents of the genomic DNA of both strains JW/IW-1228P and JW/ YJL-1230-7/2 were $50 \mathrm{~mol} \%$...."; and in the formal descriptions on pages 381 and 382: "The $\mathrm{G}+\mathrm{C}$ mol of the DNA is around 50..." The sentences should read: "The $\mathrm{G}+\mathrm{C}$ mol\% of the genomic DNA was $46.3 \pm 0.7$ $\%(n=4)$ for Thermosediminibacter oceani JW/IW$1228 \mathrm{P}^{\mathrm{T}}$, and $45.2 \pm 0.7(n=6)$ for Thermosediminibacter litoriperuensis JW/YJL-1230-7/2 ${ }^{\mathrm{T}}$."

The online version of the original article can be found at http:// dx.doi.org/10.1007/s00792-005-0453-4

\footnotetext{
Y.-J. Lee · I. D. Wagner · M. E. Brice · V. V. Kevbrin

J. Wiegel $(\bowtie)$

Department of Microbiology, University of Georgia,

527 Biological Sciences Building, 1000 Cedar Street,

Athens, GA 30602-2605, USA

E-mail: jwiegel@uga.edu

Tel.: + 1-706-5422651

Fax: + 1-706-5422651

C. S. Romanek

Department of Geology, University of Georgia,

Athens, GA 30602, USA

G. L. Mills · Y.-J. Lee · C. S. Romanek

Savannah River Ecology Laboratory, Aiken,

SC 29802, USA
} 